\title{
Learning English Vocabulary through Online Games: Case Study of Students in 4th Grade of State Elementary School (SDN) Jombor 01, Sukoharjo, Central Java, Indonesia
}

\author{
Veronika U.P*; Arianti, A; Nurnaningsih; Astuti, P.I \\ Universitas Veteran Bangun Nusantara of Sukoharjo, Central Java, Indonesia \\ Email: pratiwiunun@yahoo.co.id
}

http://dx.doi.org/10.18415/ijmmu.v5i4.433

\begin{abstract}
The Indonesian government issued a policy that English is an International language that must be studied and taught in our schools. This education should start from the level of kindergarten to college. In the context of teaching in schools such as junior high, high school and vocational high school, English is a compulsory subject that is tested nationally (national final exam). Although English has been a compulsory subject, the results obtained from English lessons are not yet satisfying. Learning activities are one of the stages that determine the success of student learning. Efforts to improve the quality of education and teaching can be carried out on various components such as: students, teachers, indicators of learning, content, methods, media, and evaluation. This research focuses on teaching vocabulary using Clash of Clans Games. Through new applications based on game technology in teaching, students are expected to be interested and contribute to the mastery of their vocabulary in English. Of course the strategy of mastering material is effectively obtained through applying Clash of Clans Games. The method used in this study is descriptive-qualitative. The purpose of this study is to explain the Clash of Clans Games to teach Vocabulary for fourth grade students of State Elementary School of Jombor, Sukoharjo in Central Java, Indonesia.
\end{abstract}

Keywords: Clash of Clans; Vocabulary; Effective Teaching; Games

\section{Introduction}

Learning vocabulary through games has gained much attention from language researchers. Donmus (2010) believes that "implementing games into parts of education has been shown to improve student language vocabulary mastery while making language education seem enjoyable" (p. 1497). This is relevant to the opinion of Kuzu and Ural (cited in Donmus., 2010, p. 1499) that "when games and education are combined, they synergize with entertaining education. Students who learn through the use of games produce positive moods and attitudes and students are more motivated studying time".

This study examines the effects of using games on learning vocabulary in English as a foreign language (EFL). Vocabulary in English is mostly taught out of context as words separately. Whereas the 
mainstream of research in this field states that the way to teach vocabulary separately cannot be learned, for this reason teaching needs to be done through the media of games (Al Neyadi., 2007).

English has become an important language in the current global era. All students and nonstudents are required to be able to communicate in international languages. To prepare students for mastering English as an international language, elementary school teachers need the right method to teach English to students. The proportion of teaching materials for elementary students is different from adult students. Teaching materials for elementary students emphasize the ability to enrich their English vocabulary.

How to teach vocabulary may not be the same as teaching vocabulary to adult students. They have different motivations and characteristics. Characteristically, elementary students are classified as early and young learners who are unique and interesting, thus cognitively teachers are required to have high creativity and produce many innovations and ideas in teaching English at this level. Of course this will be a difficult obstacle when a teacher cannot motivate these young students. The motivation of young learners in learning is only to get new things in their lives while playing. That is why they only want to learn through an interactive learning method and application through games. As early learners, students of elementary school are generally classified as having very limited vocabulary, some of the obstacles faced are memorizing meaning, and pronouncing vocabulary according to spelling that is justified in Standard English. Vocabulary is a very important and most basic thing in languages, especially foreign languages. Without adequate vocabulary mastery, a person cannot communicate effectively or express his ideas in oral or written form.

Clash of Clans or abbreviated COC is a game that is in great demand and played by some children aged over 10 years. The impact of this game has succeeded in causing concern among parents. Although no violence was found in this game, it still worried that a child became addicted. On the other hand, Clash of Clans is a typical strategy game, each player is required to initiate and develop a good strategy so that the village or kingdom will not be easily subdued or colonized by colonies from other kingdoms (enemies). Through this game, in addition to children being taught about how to organize strategies, this also allows them to manually learn in order to protect themselves from enemy attacks, be taught about how to visualize, and interact with their groups. And most importantly of all these aspects, children will also be widely introduced to new vocabulary in English, so that inevitably they learn English indirectly. This is what prompted the research team to examine the benefits of Clash of Clans Games in the field of teaching.

This study is expected to provide several benefits for students and teachers. First students will be projected to get better learning outcomes, their English skills can be better especially regarding new vocabulary mastery. Secondly, teachers can also innovate by using other more interesting English language teaching strategies. The expected outcome of this study is that it is expected that the fourth grade elementary school students will effectively learn English and master new vocabulary through the Clash of Clans based learning system.

\section{Literature Review}

Every learning and teaching activity is expected to have a goal to be achieved, as well as in this study, this research also has the goal to be achieved by seeing the reality that occurs in learning activities in classrooms at schools. 


\section{Teacher and Researcher}

\section{Learning Vocabulary through $\mathrm{COC}$ \\ Games}

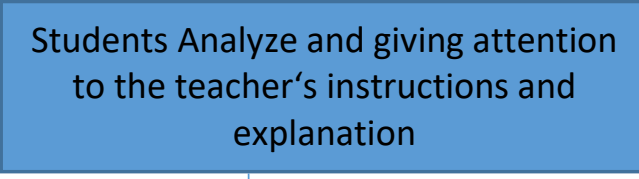

\section{Students make interaction}

\section{The students start to play $\mathrm{COC}$ Games}

\section{The students' ability in learning vocabulary}

Fig. 1 Review of related studies

Table 1 Roadmap of related research activities

\begin{tabular}{|c|c|c|c|c|}
\hline \multicolumn{2}{|c|}{ Review of related studies } & \multirow{2}{*}{$\begin{array}{l}\text { Using Cluster } \\
\text { Research }\end{array}$} & \multirow{2}{*}{$\begin{array}{l}\text { Possible Future } \\
\text { Research } \\
\text { Development }\end{array}$} & \multirow{2}{*}{$\begin{array}{l}\text { Objectives to be } \\
\text { pursued }\end{array}$} \\
\hline Another Recent study & $\begin{array}{l}\text { Related study have } \\
\text { been done in the area }\end{array}$ & & & \\
\hline $\begin{array}{l}\text { 1. Improving The Students' } \\
\text { Achievement In Writing } \\
\text { Descriptive Paragraphs By } \\
\text { Appliying Think Talk Write } \\
\text { Strategy By Yohana Faulina } \\
\text { Tambunan }\end{array}$ & $\begin{array}{l}\text { 1. Improving Writing } \\
\text { Skills on } \\
\text { Highschool } \\
\text { Students of Grade } \\
\text { X } 1 \text { of } \\
\text { Muhammadiyah, } \\
\text { Sukoharjo through } \\
\text { Think, Talk, Share } \\
\text { Strategy } \\
\text { 2. The Use of Circle } \\
\text { Games In Teaching } \\
\text { For Young } \\
\text { Learners }\end{array}$ & $\begin{array}{l}\text { The Use of Clash of } \\
\text { Clans Games for } \\
\text { Teaching } \\
\text { Vocabularies in 4th } \\
\text { Grade Students of } \\
\text { SDN Jombor, } \\
\text { Sukoharjo }\end{array}$ & $\begin{array}{l}\text { Trying another more } \\
\text { attractive strategy for } \\
\text { mastering English } \\
\text { vocabulary, thu it } \\
\text { increases the students' } \\
\text { English skill }\end{array}$ & $\begin{array}{l}\text { Students' } \\
\text { Knowledge } \\
\text { regarding new } \\
\text { vocabulary is } \\
\text { increasing. It is } \\
\text { expected that } \\
\text { Teachers will get } \\
\text { new innovations in } \\
\text { teaching English } \\
\text { for students of } \\
\text { elementary school. }\end{array}$ \\
\hline
\end{tabular}


Teaching method and strategy such as using games are very rarely used to both language teaching and learning vocabulary. Games can be helpful for teachers in creating contexts where language is useful and meaningful. Wright, Betteridge and Buck (cited in Rohani \& Pourgharib., 2013, p. 3541) believe that "By using games, teachers can create various contexts in which students must use language to communicate, exchange information and express their own opinions.

To effectively promote learning, the game must include ways for students to reflect on and explain what is happening. In fact, learning cannot occur without time for reflection. The teacher must encourage students to use the game in their learning process. They also need to monitor the use of these students' vocabulary games to ensure that the structure and rules of the game do not rank higher than learning. Learning vocabulary through games is one of the most effective and interesting ways that can be applied in the classroom.

The purpose of this study was to find out the benefits of Clash of Clans Games in teaching Vocabulary of fourth grade students of Jombor Elementary School. This research is expected to provide several benefits for students and teachers. First, students will get better learning outcomes, they will have better English language skills especially for the addition of new vocabulary. Secondly, teachers can also be innovative through using other more interesting English language teaching strategies. The expected output in this study is the increased knowledge of fourth grade elementary school students in understanding new vocabulary using Clash of Clans Games. And third, there should be a good cooperation between teacher and students at the time of learning English to gain a better and condusive classroom activities.

\section{Methodology}

This is qualitative-descriptive study which took the research subject from students of elementary school in 4 grade. These subjects were considered as beginners in learning English for the same time they knew and learned English. State Elemetary School of Jombor 1, Sukoharjo as the place where this study was conducted. The data used in this study is in the form of Clash of Clans Games. While the data source is 4th grade students of State Elementary School of Jombor, Sukoharjo, Central Java. To collect data before and after the assessment of things like the following is urgently necessary, namely: 1) Interviews with the English subject teachers and students of 4 grade, this interview was aimed to see how far the students' vocabulary progress; 2) Observation concerning the English learning process through media of Clash of Clans Games aims to observe the way teachers teaching the English subject by applying a more interesting teaching technique which is through games; 3) Implementation of Clash of Clans Games in learning, i.e., an English teacher would ask students to play thois game of either individually or in groups; 4) the method of documentation was primarily done through recording the Clash of Clans application; 5) The technique aims to obtain more accurate research data. If it possible, the data collection technique can be a combination of the three, namely interviews, observation and documentation, which is further called triangulation.

In a qualitative research, the main instruments are the one who conducts a study or members of the research team. However, in this study the main instrument is taken through applying both interview and observation techniques carried out through making list checking into several phases such as viewing and filling out informative data about students' abilities in remembering the new vocabulary they get from playing Clash of Clans games and documentation methods in photos and recording data forms. Data validity/ validity of the data was tested by triangulation of the three data that had been obtained. That is, by testing credibility carried out by extension of observation, increasing perseverance and much discussion with team mates. 


\section{Results and Discussion}

The results of this study elaborate that students are interested and enthusiastic in attending the English lessons, since students have already known the Clash of Clans very well. However, students may not know the meaning of the Clash of Clans Game. In this case, English teachers help students by translating new vocabulary in COC games. Previously, the research team conducted observations at State Elementary School (SDN) Jombor 01 of Sukoharjo, and what they got was that students did not master the English vocabulary. Through game play as an English language learning media, then the English language teacher tested on the 4 th grade students.

Whenever the learning English is begining, students are invited to the school computer lab and were instructed to open the COC games application. The teacher initially shows the COC application via mobile phone. Students look very interested in this game application, so they scramble to try this COC application. Initially students did not know each meaning of either spoken and written vocabularies, by the help of their English teacher, they gradually began to master new introducued vocabulary in English, ranging from the names use of stone, army, battle, gun, store, etc.

Having introduced the mastery vocabulary based on the COC game application to 4th grade students of Jombor Sukoharjo Elementary School proved that the level of students' vocabulary mastery increased. They not only know the vocabulary around them but they also know vocabulary through games. The author feels the need to identify existing problems in order to determine the teaching and learning process and the condition of vocabulary mastery of 4th grade students of SDN Jombor 01 Sukoharjo. Related to that, the author observes and finds several problems based on the results of observations, the results of interviews, the results of the questionnaire, as well as the teacher's statement that students lack mastery of vocabulary. Based on observations, it was found that teachers lacked innovation in teaching English, which consequently lead the students felt bored. The results of the questionnaire indicate that most students do not like English lessons, especially in the teaching method applied by the teacher. In addition, the teacher does not use an interesting strategy in teaching English. Based on these facts, it can be concluded that teaching vocabulary by using COC games has a positive impact on students, in the sense that students become more familiar with new vocabulary not only from the vocabulary they meet daily but also get new vocabulary from COC games. Steps for using COC games can be seen in the attachment History Saved Community.

\section{Clash of Clans Games}

To provide good education services for early childhood we should understand their characteristics and find out the needs that are appropriate to their level of development, which prone to learn while play. In addition to that, playing is a process of learning for early school learners, for that reason the teeacher would normally provide activities to them in a hope it will fit to their world. Because the game is considered a form of media which is easily learned by children rather than memorizing vocabulary.

Clash of Clans (COC) is an online multiplayer game where a player builds communities, trains troops, and attacks other players to get gold and panacea, and Dark Elixir, which can be used to build defenses that protect themselves from being attacked by other players, and to train and increase the strength of the army. According to Supercell, clash of clans games are 'An Epic Combat Strategy Game'. This game requires careful thinking, planning and resource management to be successful. Players must also work hard to plan and build villages from the start, preparing the defenses needed to fend off enemy attacks and make the army stronger. The benefits of Clash of Clans Games are: 1) Players will learn that it takes investment of time, effort and patience to achieve success; 2) The player will experience an immeasurable sense of satisfaction seeing something that happens according to plan; 3) Players can learn 
about the consequences (or rewards) of taking risks; 4) Players develop the ability to analyze information and make decisions; 5) Players participate in experiential learning without actually suffering the consequences of poor decision making; 6) Players learn the ability to overcome bad things and how to get up and recover from the problem; 7) Players learn the value of perseverance and learn from mistakes; 8) Players gain experience from collaborative collaboration with other players

\section{Identifying the Learning Methods and Learning Activities}

Learning activities are one of the stages that determine the success of student learning. Efforts to improve the quality of education and teaching can be carried out on various components such as: students, teachers, indicators of learning, content, methods, media, and evaluation. Teachers other than as facilitators as well as mediators in the components of teaching have a very important role in achieving the learning objectives and greatly determine the success of the education process, because teachers are directly involved in the process of learning teaching. Student learning outcomes were even more influenced by the teaching strategies carried out by the teacher. The way students learn is also related to their learning motivation, as well as the strategies taught by the teacher both cooperatively and in groups. Therefore the teacher is obliged to condition his students so that they are truly ready to receive lessons, especially English, in this case vocabulary. It is undeniable that vocabulary grows through incidental learning such as through continuous exposure, repeated for language that is easy to understand in reading, listening, speaking, and writing exercises (Krashen., 1984: 74). In learning English, vocabulary plays an important role in four English language skills, speaking, reading, listening, and writing as Schmite and Mc. Carthy (1997: 6) emphasizes that vocabulary has an important role in language skills. At Jombor Elementary School, the students experienced many difficulties in learning English, because of the lack of vocabularies they had mastered, supported by English only given as local content, therefore, there were many obstacles they faced. Because of this problem, the research team was moved to conduct vocabulary research by applying new strategies that made students interested in adding vocabulary in English. Namely by using Clash of Clans Games History Saved Community.

\section{Teaching English for Children}

Teaching English specifically for children, is not easy because as a teacher, we should comprehensively comprehend the developmental psychology of children relevant to language learning. Piaget (cited in Kasihani., 2007, p. 6) states that:

Children learn from the surrounding environment by developing what they already have and will interact with what is found around them. In interacting, they will take action to solve the problem and this is where the learning process takes place.

Zulkifl (2014, p. 178-179) has classified students in their research into several characteristics, including; 1) Children are always active in exploring the environment, gaining knowledge and experience. The environment explored here includes physical, social, information and ideological. Children build their understanding of how things work, including language as a system and how to communicate; 2) Children know many things before school. For example, knowledge of traffic signs, traffic lights, and favorite toy brand names and food; 3) Children tend to learn things in the form of scripts holistically. This trend is well reflected in children's play: "Schools, teachers and students," "doctors and patients" etc. In this concep, children learn well when they perceive the learning is meaningful, interesting, and fun; 4) Learning becomes meaningful for children at the time making decisions related to their needs. Learning so that they can choose based on what they consider important and useful. Children learn best when they make their own choices. 
Vocabulary mastery is one of the basic components for mastering English as a foreign language at the elementary, secondary and advanced school level. In learning four language skills (listening, speaking, reading and writing), vocabulary is one of the basic components that must be mastered. This is natural, considering that four language skills require knowledge of words because they will not get anything without vocabulary. The more students' mastery on the targeted vocabularies, the better their English will be. By having a limited vocabulary, students will find it difficult to master reading and other skills. By having good vocabulary mastery means students have the ability to understand and use the vocabulary at different contextual language use.

\section{Conclusion}

Based on the results of the study, the teaching method through applying Clash of Clans Games to teach vocabulary for 4th grade students of Jombor 01 Elementary School is quite useful, this can be seen from the results of interviews between students and English teachers at Jombor 01 Elementary School, as well as observations when teachers teach vocabulary with Clash of Clans games, students were enthusiastic to try the application and were enthusiastic to try the new instroduced meanings of the COC games. This study has some implications, few suggestions need to be taken into consideration: 1) Students are expected to increase their vocabulary mastery, this can be well begun from the English teacher; 2) Similar activities need to be carried out in other regions, this will bring about consequence in which the teaching of English will be more varied through interesting methods.

\section{References}

Ary, Donald. (1979). Introduction to Research in Education. New York: Holt, Rinehart and Winston.

Al Neyadi, O. (2007). The Effects of Using Games to Reinforce Vocabulary Learning. In Marifa H.C.T. (Ed.), Action Research and Initial Teacher Education in the UAE (p. 99- 107). HCT Press, UAE.

Astuti, EP. (2014). Improving Students’ Writing Skills on Recount Text. ejournal.unp.ac.id

Beck, Robert H. (1960). Curriculum in the Modern Elementary School. Pretice-Hall Inc. Engle Wood Cliffs.

Brown, H. Douglas. (2000). Principles of Language Learning and Teaching. White Plains, NY: Addison Wesley Longman, Inc.

Burns, Ann. (1999). Collaborative Action Research for English Language Teachers. Cambridge University Press.

Cline. F, Johnstone. C, and King. T. (2006). Focus Group Reactions to Three Definition of Reading. Minneapolis. Minnesota.

Donmus, V. (2010). The Use of Social Networks in Educational Computer-Game based Foreign Language Learning. Social and Behavioral Sciences, 9: 1497-1503.

Departemen Pendidikan dan kebudayaan. Kantor Wilayah Jawa Timur. (1994). SK Kanwil Departemen Pendidikan dan Kebudayaan. No. 1702/105/1994. Tanggal 30 Maret, 1994.

Hopkin, David. (1992). A Teacher's Guide to Classroom Research. Great Buckingham: Open University Press. 
Maulida, Nova. (2013). Think Talk Write Strategy For Teaching Descriptive Writing. Jurnal Pendidikan Bahasa Inggris STKIP PGRI Sidoarjo, 1(1): April 2013, ISSN: 2337-9278.

Mills, E.,G. (2000). Action Research. A Guide for Teacher Researcher. Cambridge: Cambridge University Press.

Paul, David. (2003). Teaching English to Children in Asia. Hongkong: Longman Asia ELT.

Saffarian, R., \& Gorjian, B. (2012). Effect of Computer-based Video Games for Vocabulary Acquisition Among Young Children: An Experimental Study. Journal of Comparative Literature and Culture, 1(3): 44-48.

Scott, W.A. dan L.H. Ytreberg. (1990). Teaching English to Children. London: Longman.

Suyanto, Kasihani K.E. (2007). English For Young Learners. Bumi Aksara. Retrieved from: http://panduanclashofclans.wordpress.com/2014/05/07/sejarah-clash-of-clans/15-12-2014/07.26.

\section{Copyrights}

Copyright for this article is retained by the author(s), with first publication rights granted to the journal.

This is an open-access article distributed under the terms and conditions of the Creative Commons Attribution license (http://creativecommons.org/licenses/by/4.0/). 